\title{
EMLÉKEZÉSEK ÉLETEMBŐL
}

Kicsoda ö, micsoda ö?

Szontagh Gusztáv (1793-1858) nem tartozik a magyar gondolkodástörténet kanonikus alakjai közé, pedig a reformkor és a neoabszolutizmus korának jeles szerzője, a maga korszakának ismert személyisége. A magyar kultúra területeinek intézményes elkülönülése és a kulturális szerepek megszilárdulása elötti korszak alakjaként, a mából nézve megmosolyogtatóan sokféle területen jelentkezik, és sokféle szerepet kipróbál. Az előző század végén születik, a katonai pályát választja, majd korai nyugalomba vonulása után számos dologba fog. Kísérletezik szépirodalommal: verseket ír, drámai jelenetben ábrázolja a felső-magyarországi nyelvi megosztottságot. Irodalmi kritikákat publikál: a korszak induló folyóirataiban, szépirodalmi és bölcseleti munkák rendszeres szemlézésével egyike lesz az első - irodalmi teljesítményeket nyilvánosan megítélő - kritikusoknak. Rendszeres szereplöje a folyóiratvitáknak: fáradhatatlan kedvvel bocsátkozik bele a különböző nyilvános polémiákba. Mezőgazdasági értekezéseket tesz közzé: a dinnye- és a dohánytermesztésnek szentelt kötetei a korszak több kiadást megérő sikerkönyveinek számítanak. Filozófiai tanulmányokat és könyveket szerez: önálló művei között ír bölcseleti bevezetést, dolgoz ki társadalomfilozófiát, élete alkonyán összefoglalja filozófiai rendszerét. És élete utolsó évtizedében készít egy terjedelmes visszaemlékezést, amely azonban befejezetlenül és részben töredékben marad: most azonban, elkötelezett kutatójának, Mester Bélának szorgalmas munkája nyomán, íme, végre elénk került.

Ha egyáltalán valamit, kizárólag azt szokás tudni róla, hogy a korszak „,egyezményes-harmonisztikus filozófiai iskolájának" egyik alapítója és meghatározó gondolkodója. Elsősorban filozófus tehát, akit éppen az határoz meg, hogy egy határozott bölcseleti iskolához tartozik. Maga az iskola ugyanakkor valójában inkább csupán konstrukció: neki magának és kortársának-pályatársának, Hetényi Jánosnak közös teremtménye. A hazai filozófiai elmaradottság okainak föltárására kiírt akadémiai pályakérdés egyik díjazottja, Hetényi a filozófiát harmonikus „életszépítésként" határozza meg, egyfelől. Az önálló magyar filozófia megteremtését célul tüző Szontagh ebben, a Hetényi-féle „egyezményes-harmonisztikus” bölcseletben pillantja meg a lehetséges magyar filozófiát, másfelöl. Az egymást figyelemmel kísérő és egymásra reflektáló két szerző munkássága így összekapcsolódik. „Iskolájuk” nem képez határozottan megragadható, önálló - azonos hagyományokra támaszkodó, hasonló problémákat vizsgáló és koherens fogalomrendszert alkalmazó - filozófiai irányzatot. A „magyar gondolkodásmóddal” adekvát és az ellentéteket harmóniába hozó „egyezményes nemzeti filozófia” 
konstrukciója mégis létrejön és fönnmarad. Megszilárdulásához, érdekes módon, épp az ,iskola” legjelentősebb ellenfele, a hegeliánus Erdélyi János - a magyar kultúra kanonikus alakja - járul hozzá jelentősen, aki híres vitairatában a filozófia általánosságfogalma felől támadja meg az „egyezményesek” „,nemzeti filozófiáját”. Mindenesetre, az elmúlt közel két században Szontagh neve az „egyezményes filozófia” fogalmával összefüggésben maradt fönn: így, „egyezményes” filozófusként értelmezik őt a hazai filozófiai múlt kutatásának egymást követő - pozitivista, szellemtörténeti, majd marxista elöföltevésekkel dolgozó - nemzedékei.

Ehhez képest - ez a legelső, amit a mostani kötet ismertetésébe fogva meg kell említenünk - a visszaemlékezésben egyetlenegyszer sem kerül elő az „,egyezményes filozófia” fogalma. Sem a szerkesztő, Mester Béla informatív bevezető tanulmánya, sem maga Szontagh szövege nem utal rá, hogy a szerző ,egyezményes" volna. Mester filozófiatörténészi munkásságának már eddig is határozott törekvése volt, hogy Szontagh alakját eloldja az „,egyezményes iskolától”, és önálló-eredeti gondolkodóként mutassa föl. Ez a törekvés most, a memoár kiadásával fontos érvhez jutott: pályája alkonyán szerzett visszaemlékezésében, íme, ő maga, Szontagh sem azonosítja önmagát „egyezményesként”.

A szövegkorpusz, több utalásból kikövetkeztethetően, valamikor 1849 második fele és 1851 tavasza között keletkezik, közvetlenül Világos után tehát. Szontagh ötvenes éveinek második felében jár; úgy érzi, elérkezett a számvetés ideje, vissza lehet tekintenie a pályájára. A reformkori nyilvánosság fórumai megszüntek; az egész felnőtt életében írással foglalkozó, a nyilvánosság közegében tevékenykedő gondolkodó így kényszerüen a maga számára kell följegyzéseket készítsen. Világos traumája pedig a nemzethalál vízióját látszik valóra váltani; be kell számolnia a történtekről, el kell gondolkoznia a nemzeti lét és nemlét alternatíváján. Az emlékirat megszületésében, a kötet bevezetésében Mester finoman utal erre, mindhárom szempont tetten érhető. Az egyéni számvetés alkalma, a nyilvánosság közege nélkül maradt szerző kényszerủ írásterápiája és a történelmi kataklizma tanújának történetfilozófiai töprengése: az Emlékezések életemből megszületésében mindegyik szerepet játszik.

A vállalkozás, ugye, befejezetlen marad, szövegét szerzője nem tudja kötetté szerkeszteni, a mai olvasó számára szembetűnő hát, milyen sok önálló müfaji rétege különül el egymástól. Megvan benne, persze, maga az önéletrajz. A német eredetű köznemesi család gyermeke beszámol gyökereiről, számba veszi fölmenőit, megrajzolja szülei alakját, elmeséli gyermekkorát, fölidézi katonaéveit, bemutatja az irodalmi életbe való bekapcsolódásának történetét. Föltűnik benne egy útleírás: katonaévei idején eljut Rómába és Nápolyba, lelkes hangú beszámolóban idézi föl ezt az útját. Beleékelődik egy társadalomtörténeti-müvészettörténeti tanulmány: olasz útja alkalmával indíttatva érzi magát, hogy eltűnődjön Olaszország polgárosultságának okain, fölidézze az olasz müvészet teljesítményeit. Megjelenik benne egy vallásbölcseleti értekezés: a szöveg egy pontján rekapitulálja 
eredetileg németül fogalmazott és kiadatlanul maradt, vallásfilozófiai tárgyú tanulmánya gondolatmenetét. És számos helyen föl-föltünnek benne filozófiai fejtegetések, mindegyre visszatérve rá, milyen filozófiai elvek alapján fogalmazta müveit, és milyen bölcseleti beállítottság mozgatta az élete alakításában és politikai törekvéseiben.

A magyar filozófia múltja iránt érdeklődő mai olvasó figyelmét kétségtelenül elsősorban ez utóbbi szövegréteg kelti föl. Ezeknek a filozófiával foglalkozó szöveghelyeknek a nyomán először is az tünik föl, hogy Szontaghnak a filozófusszerepröl vallott fölfogása határozottan szemben áll a professzionális filozófiaprofesszor, a „szobaphilosophia” művelőjének szerepfölfogásával. Mint elmeséli, életében kétszer is megkeresik filozófiaprofesszori ajánlattal, de ő mindkétszer határozottan ellenáll. A filozófiaprofesszor életidegen „szobaphilosophiájával” szemben a maga törekvéseit „öntájékozásunkra intézett philosophálás"-nak nevezi, amely az „eredménnyel megelégedve”, úgymond, ,ideiglenesen más foglalatosságoknak adhat helyet". Filozófusnak gondolja tehát magát, de a filozófiát inkább az élet személyes megformálásának valamiféle instrumentumaként fogja föl. Afféle „életbölcsességnek” tekinti tehát; a „philosophia”, azt mondja, ,az öntudatra ébredt gondolkodó meggyőződéseire s cselekedéseire nézve önmagát határozni igyekvő ember legfelsőbb tájékozódási tudománya".

Filozófiai fölfogásának középponti gondolata az idealizmus és a realizmus közötti közvetítés; pontosabban egy kettős vita: egyfelől a „szemlélődő philosophia”, az „eszményi irány”, a „valóság nélküli”, „ábrándos” idealizmus, a másfelől az „eszmeüres realismus” bírálata. A kettős bírálat alapja ismeretfilozófiai jellegü: a megismerésfolyamat empirikus kiindulópontjának fölfogása, a valóság „tárgyilagos” szemlélete, a fogalmak valóságalapjának hangsúlyozása húzódik meg a hátterében. „Philosophiám a tárgyból indul ki”, magyarázza egyik bölcseleti kitérőjében, „a tárgy és észrevétele az első, magyarázata a második”. A két bírálat közül ugyanakkor az előbbi határozottan hangsúlyosabb. Korunk, vélekedik, a „forradalom korszaka”, amelyben a „keresztény emberiség a fennállót eszmék szerint igyekszik alakítani”, következőleg manapság inkább az idealizmus elúrhodása fenyeget. Innen adódik, hogy visszaemlékezése két leggyakrabban és leghevesebben bírált alakja, érdekes módon, egyfelől az „elméleti idealista” Hegel, másfelől a „gyakorlati idealista” Kossuth. Ahogy a spekulatív-szemlélödő német filozófia föszereplöje, Hegel az élettől és a valóságtól elrugaszkodva, a „fogalom dialecticai processusa” által hamisan szerkeszti az embert, istent és a valóságot, úgy a forradalmi-fölforgató magyar politika kulcsalakja, Kossuth életidegen-doktriner radikális elveihez ragaszkodva, romba dönti az országot, és a sír szélére juttatja a nemzetet.

A kettős vita, illetve a szemlélődő filozófia/ábrándos idealizmus bírálata a szöveg számos helyén előbukkan, egyaránt alapját képezve a gondolkodó politikai állásfoglalásának, teoretikus munkásságának és gyakorlati életvezetésének. 
A vázlatosnál is rövidebben. Ez lesz, ugye, politikai filozófiájának alapja, a változatlan „stabilitással” és a fölforgató „forradalommal” egyaránt szembehelyezett „reform”-rendszerével a középpontban. Ez lesz mükritikusi ars poétikájának szíve közepe, amely szerint az ideális müalkotás az észrevétel-reprodukció által összegyüjtött anyag eszményesítő-produktív földolgozását nyújtja. Ez lesz pedagógiai gyakorlatának vezérfonala, amelyben az ,anyag” úgymond megelözi az ,alakot”, a természetrajztól indulva, a földrajzon és a történelmen át a filozófiáig jutva el. És ez lesz élete megformálásának regulája, amelyben harmonikusan egészíti ki egymást a lélek és a test fejlesztése, amelyben a bölcseleti tevékenység meg a dohány- és dinnyetermesztő testi munkálkodás egyaránt megtalálja a maga helyét.

Értékes kötet, ismeretbővítő kiadvány, elmemozdító olvasmány - mondhatjuk róla összegzésképpen. Szerkesztője, Mester Béla hatalmas munkát fektetett bele, de ezzel mintha el is bújt volna kedves hőse mögé. Mester jó másfél évtizede komolyan foglalkozik Szontaghgal; számos konferencia-előadást és nehezen megszámlálható tanulmányt szentelt az alakjának, kontribúciói pedig összességében egy részletes Szontagh-monográfia felé mutattak. Most, ezzel a kötettel mégsem a szintézis felé indult el, hanem az analízis újabb lehetőségét igyekezett megteremteni. Tudni kell a dologról, hogy önálló Szontagh-kötet - reformkori irodalmi bírálatainak válogatása - idestova kilenc évtizede, 1929-ben látott utoljára napvilágot. Azóta ez, Mester vállalkozása az első. Mint szerkesztői munkájáról beszámolva elmeséli, az Akadémia kézirattárában őrzött hagyaték a visszaemlékezés három szövegváltozatát is örzi; az eredeti autográf kéziratot össze kellett hát olvasnia a később keletkezett - valószínüleg valamely reménybeli kiadást előkészítő - másolatokkal. Az egyes szövegegységeknek meg kellett találnia a helyét, egységes kötetté komponálva a szöveganyag egészét. A kézirat korabeli nyelvi megoldásait modernizálnia kellett, lehetőleg megőrizve közben az eredeti mondatszerkesztési sajátosságokat és szerzői archaizmusokat. Azonosítania és értelmeznie kellett az idegen nyelvü - föként német - idézeteket. Minden megmagyarázandót sorra véve, bőséges jegyzetapparátussal kellett ellátnia a főszöveget. A kötet használhatóságát növelendő, végül pontos névmutatót kellett készítenie.

A névmutatóban szerepel egy bizonyos „Bella” is. Róla azt tudjuk meg, hogy nem más, mint egy „mecklenburgi kanca, hátasló”. A szeretetteljes szerkesztői figyelem mulatságos megnyilvánulásaként.

(Szontagh Gusztáv: Emlékezések életemböl. Szerk. Mester Béla [Ergo], Budapest: MTA BTK Filozófiai Intézet-Gondolat Kiadó, 2017, 184 o.)

Perecz László

filozófiatörténész 